\title{
Molecular and Crystal Structures of Some Fluorocymantrenes
}

\author{
Karlheinz Sünkel $^{1}\left[\right.$. Christian Klein-Heßling ${ }^{1}$
}

Received: 17 June 2021 / Accepted: 16 July 2021 / Published online: 22 July 2021

(c) The Author(s) 2021

\begin{abstract}
The crystal and molecular structures of the fluorocymantrenes $\left[\left(\mathrm{C}_{5} \mathrm{H}_{4} \mathrm{~F}\right) \mathrm{Mn}(\mathrm{CO})_{3}\right]$ and $\left[\left(\mathrm{C}_{5} \mathrm{H}_{5-\mathrm{n}} \mathrm{F}_{\mathrm{n}}\right) \mathrm{Mn}(\mathrm{CO})_{2}\left(\mathrm{PPh}_{3}\right)\right](\mathrm{n}=1-3)$ have been studied. The influence of the phosphine for carbonyl substitution on the bond parameters is larger than the influence of the increasing fluorine content. In most cases the $\mathrm{Mn} \rightarrow \mathrm{P}$ vector is in a transoid position relative to the fluorine substituents, and therefore the conformational parameters of the $\mathrm{PPh}_{3}$ propeller are in these cases very similar. The crystal structures show many intermolecular $\mathrm{C}-\mathrm{H} \cdots \mathrm{O}$ hydrogen bonds and only very few $\mathrm{C}-\mathrm{H} \cdots \mathrm{F}$ hydrogen bonds.
\end{abstract}

\section{Graphic Abstract}

The influence of the phosphine for carbonyl substitution on the bond parameters of the fluorocymantrenes $\left[\left(\mathrm{C}_{5} \mathrm{H}_{4} \mathrm{~F}\right) \mathrm{Mn}(\mathrm{CO})_{3}\right]$ and $\left[\left(\mathrm{C}_{5} \mathrm{H}_{5-\mathrm{n}} \mathrm{F}_{\mathrm{n}}\right) \mathrm{Mn}(\mathrm{CO})_{2}\left(\mathrm{PPh}_{3}\right)\right](\mathrm{n}=1-3)$ is larger than the influence of the increasing fluorine content.

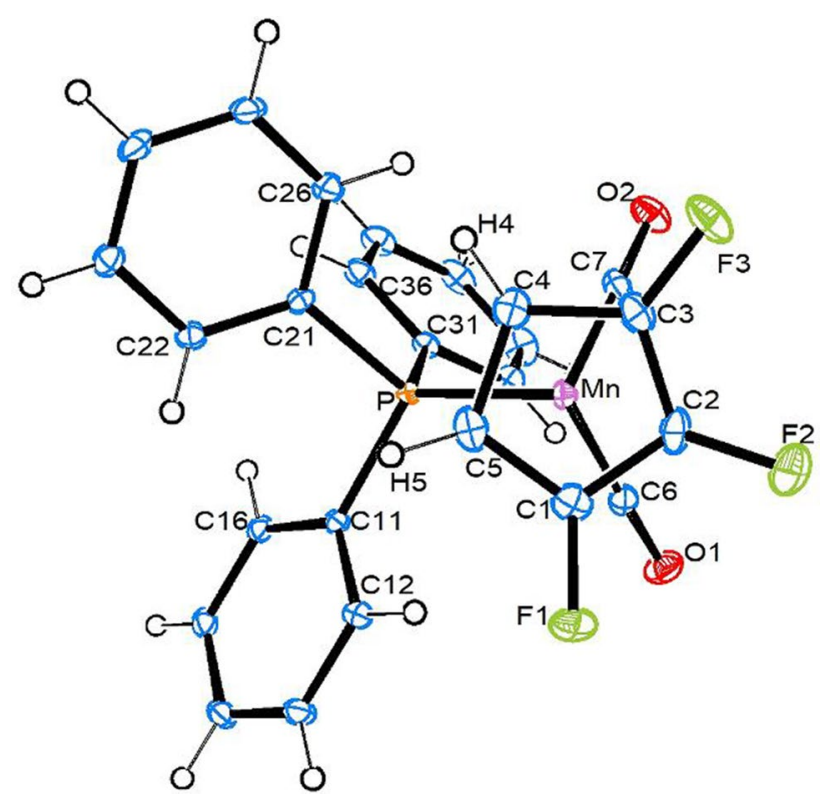

Keywords Cymantrene $\cdot$ Fluorocyclopentadienyl complexes $\cdot$ Triphenylphosphine $\cdot$ Conformational analysis

Karlheinz Sünkel

suenk@cup.uni-muenchen.de

1 Department of Chemistry, Ludwig-Maximilians-University Munich, 81377 Munich, Germany

\section{Introduction}

Fluoroorganic compounds continue to be of great importance in many areas of modern applied chemistry, e.g. materials chemistry [1], biomolecular chemistry [2] or medicinal chemistry [3,4]. At the same time, metallocenes and related organometallic compounds have left the labs of 
fundamental research and dived into the realm of applied chemistry, particularly medicinal chemistry [5-7]. Thus, it was not surprising that recently the idea was born, to join these two important areas [8]. This became possible (at least for the compounds bearing a fluorine atom bound directly to the cyclopentadienyl ring) with our introduction of $N$-fluorobenzenesulfonimide (NFSI) as electrophilic fluorination reagent in ferrocene chemistry 10 years ago [9]. Before 2011, fluorometallocenes were not more than a lab curiosity, being obtainable either only in very low yields $[10,11]$ or by experimental techniques unavailable to most labs [12-14]. Most of the experimental work on fluorometallocenes after 2011 was done with the ferrocene system, mainly by the group of Erb at the University of Rennes [8, $15,16]$. Although fluorocymantrene was the very first fluorometallocene prepared [10], there were no other reports on it until very recently [17]. This seems astonishing, considering the still active research on cymantrene derivatives in cancer research on one hand $[18,19]$, and the importance of ${ }^{18} \mathrm{~F}$-labeled arenes in Positron Emission Tomography (PET) [4]. This imbalance in general research is also mirrored in the crystal structure domain. There are 43 entries of fluorometallocenes in the Cambridge Structure Database [20] (CSD-version 5.42, accessed on June 10, 2021), of which 39 are derivatives of ferrocene (all studied between 2011 and 2020) and three of ruthenocene (all reported in the 1990s). Here we report our crystal structure determinations of $\left[\left(\mathrm{C}_{5} \mathrm{H}_{4} \mathrm{~F}\right) \mathrm{Mn}(\mathrm{CO})_{3}\right](\mathbf{1})$ and $\left[\left(\mathrm{C}_{5} \mathrm{H}_{5-\mathrm{n}} \mathrm{F}_{\mathrm{n}}\right) \mathrm{Mn}(\mathrm{CO})_{2}\left(\mathrm{PPh}_{3}\right)\right]$ $(\mathrm{n}=1-3 ; \mathbf{2}-\mathbf{4})$.

\section{Experimental}

The synthesis and characterization of all compounds was published elsewhere recently [17]. Although the spectroscopic data have already been reported, the NMR data are collected here once again:

\section{${ }^{1}$ H-NMR}

1: $\delta=4.71 \mathrm{~m}, 4.45 \mathrm{~m} ; 2: \delta=7.46-7.33 \mathrm{~m}, 4.23 \mathrm{~m}, 3.94 \mathrm{~m}$; 3: $\delta=7.66-7.20 \mathrm{~m}, 4.31 \mathrm{~m}, 3.48 \mathrm{~m} ; 4: \delta=3.44 \mathrm{~m}$.

\section{${ }^{19}$ F-NMR}

1: $\delta=-165.0 ; 2: \delta=-171.1 ; 3: \delta=-188.0 ; 4: \delta=-187.8$ $(\mathrm{d}, 18 \mathrm{~Hz}),-203.7$ (td, $18 \mathrm{~Hz} / 4 \mathrm{~Hz})$

\section{${ }^{31}$ P-NMR}

2: $\delta=91.6 ; 3: \delta=88.50 ; \mathbf{4}: \delta=87.8$.

\section{${ }^{13}$ C-NMR}

1: $\delta=223.9,143.9(\mathrm{~d}, 276 \mathrm{~Hz}), 75.9(\mathrm{~d}, 4 \mathrm{~Hz}), 66.8(\mathrm{~d}$, $13 \mathrm{~Hz})$.

2: $\delta=231.4,142.9(\mathrm{~d}, 271 \mathrm{~Hz}), 137.7(\mathrm{~d}, 41 \mathrm{~Hz}), 133.1$ (d, $11 \mathrm{~Hz}), 128.3$ (d, $9 \mathrm{~Hz}), 129.8,76.1$ (d, $4 \mathrm{~Hz}), 67.5$ (d, $13 \mathrm{~Hz})$.

3: $\delta=230.5,137.1(\mathrm{~d}, 42 \mathrm{~Hz}), 133.1(\mathrm{~d}, 10 \mathrm{~Hz}), 128.4$ $(\mathrm{d}, 9 \mathrm{~Hz}), 129.9,127.6(\mathrm{dd}, 272$ and $11 \mathrm{~Hz}), 67.7,62.7$.

4: $\delta=229.0,136.6(\mathrm{~d}, 42 \mathrm{~Hz}), 133.1(\mathrm{~d}, 11 \mathrm{~Hz}), 128.5$ (d, $10 \mathrm{~Hz}), 130.1$ (d, $2 \mathrm{~Hz}), 123.8$ (ddd, 276/8/4 Hz), 114.7 (dt, 274/11 Hz), 53.2 (dd, 8/5 Hz).

The pre-purified compounds obtained after column chromatography were dissolved at r.t. in the minimum amount of an 85:15 mixture of petroleum ether/diethyl ether and transferred in an open vial to a refrigerator operating at $+5{ }^{\circ} \mathrm{C}$. After standing for several days and slow evaporation of the solvent, yellow crystals were obtained.

Crystals of $\mathbf{1}$ and $\mathbf{3}$ were measured on an Oxford XCALIBUR 2 diffractometer and crystals of $\mathbf{2}$ and $\mathbf{4}$ on a Bruker D8 Venture diffractometer. The obtained datasets were examined by the WINGX program suite [21-24]. The structure of 1 was solved with SIR 97 and the others with SHELXT. Refinements of all structures were performed with SHELXL 2018/3. Table 1 presents general experimental details of the structure determinations.

\section{Special Remarks on the Structure Refinements}

The four hydrogen atoms of compound $\mathbf{1}$ were localized on difference Fourier maps. Their positions were refined, with $\mathrm{U}_{\text {iso }}$ values fixed at 1.2 times the equivalent $\mathrm{U}_{\text {iso }}$ values of the attached carbon atoms, and restrained to be all of the same $\mathrm{CH}$ bond length.

All hydrogen atoms of compound $\mathbf{2}$ were geometrically positioned, using the standard riding model with all $\mathrm{U}_{\text {iso }}$ fixed at 1.2 times the equivalent $U_{\text {iso }}$ values of the attached carbon atoms. In both independent molecules there was found additional electron density next to one cyclopentadienyl $\mathrm{C}-\mathrm{H}$ bond, each. In both molecules this occurred in relative 3-position to the first $\mathrm{F}$-atom (hydrogen $\mathrm{H} 5$ in molecule A and $\mathrm{H} 35$ in molecule B). It was possible to refine a $\mathrm{H} / \mathrm{F}$ disorder model for the atom pair $\mathrm{H} 5 / \mathrm{F} 1 \mathrm{~A}$ to a relative occupancy $0.869 / 0.131$, and for the pair H35/ F2A to a relative occupancy $0.97 / 0.03$ (and vice versa for H3/F1 and H33/F2, respectively; see also "Discussion" section on this issue).

The original data collection of compound 3 was performed on a monoclinic $I$ cell with $a=17.1994(5)$, $b=13.4797(4), c=18.5495(5) \AA$ and $\beta=100.184(3)^{\circ}$. Examination by PLATON suggested transfer to space group 
Table 1 Experimental data of the crystal structure determinations

\begin{tabular}{|c|c|c|c|c|}
\hline & 1 & 2 & 3 & 4 \\
\hline Empirical formula & $\mathrm{C}_{8} \mathrm{H}_{4} \mathrm{FMnO}_{3}$ & $\mathrm{C}_{25} \mathrm{H}_{19} \mathrm{FMnO}_{2} \mathrm{P}$ & $\mathrm{C}_{25} \mathrm{H}_{18} \mathrm{~F}_{2} \mathrm{MnO}_{2} \mathrm{P}$ & $\mathrm{C}_{25} \mathrm{H}_{17} \mathrm{~F}_{3} \mathrm{MnO}_{2} \mathrm{P}$ \\
\hline Formula weight & 222.05 & 456.31 & 474.30 & 492.29 \\
\hline Crystal system & Monoclinic & Triclinic & Monoclinic & Monoclinic \\
\hline Space group & $P 2_{1} / n$ & $P^{-} 1$ & $C 2 / c$ & $C 2 / c$ \\
\hline Temperature $(\mathrm{K})$ & 123 & 100 & 173 & 100 \\
\hline Crystal size $(\mathrm{mm})$ & $0.22 \times 0.21 \times 0.12$ & $0.10 \times 0.07 \times 0.04$ & $0.43 \times 0.30 \times 0.23$ & $0.10 \times 0.07 \times 0.04$ \\
\hline$a(\AA)$ & $10.8503(6)$ & $9.3676(15)$ & $22.9584(9)$ & $22.7937(6)$ \\
\hline$b$ & $6.9206(3)$ & $13.524(2)$ & $13.4797(4)$ & $13.6951(3)$ \\
\hline$c$ & $11.5547(7)$ & $17.103(3)$ & $17.1994(5)$ & $18.4224(4)$ \\
\hline$\alpha\left({ }^{\circ}\right)$ & & $85.847(6)$ & & \\
\hline$\beta$ & $114.182(7)$ & $74.738(5)$ & $127.323(2)$ & $132.255(1)$ \\
\hline$\gamma$ & & $89.055(6)$ & & \\
\hline $\mathrm{V}\left(\AA^{3}\right)$ & $791.51(8)$ & $2084.8(6)$ & $4232.8(3)$ & $4256.49(18)$ \\
\hline $\mathrm{Z}$ & 4 & 4 & 8 & 8 \\
\hline$\mu\left(\mathrm{mm}^{-1}\right)$ & 1.65 & 0.74 & 0.74 & 0.74 \\
\hline $\mathrm{T}_{\min }, \mathrm{T}_{\max }$ & $0.973,1$ & $0.698,0.746$ & $0.964,1$ & $0.707,0.746$ \\
\hline Measured/independent reflect & $4864 / 1797$ & $26,490 / 12,714$ & $15,135 / 5244$ & $32,941 / 4873$ \\
\hline $\mathrm{R}_{\text {int }}$ & 0.031 & 0.032 & 0.029 & 0.028 \\
\hline Observed reflect. $[\mathrm{I}>2 \sigma(\mathrm{I})]$ & 1567 & 10,079 & 3940 & 4387 \\
\hline Data/restraints/parameters & $1797 / 18 / 130$ & $12,714 / 7 / 549$ & $5244 / 4 / 285$ & $4873 / 1 / 290$ \\
\hline GOOF & 1.08 & 1.10 & 1.04 & 1.10 \\
\hline $\mathrm{R} 1, \mathrm{wR} 2[\mathrm{I}>2 \sigma(\mathrm{I})]$ & $0.062,0.174$ & $0.058,0.182$ & $0.037,0.089$ & $0.032,0.080$ \\
\hline R1, wR2 [all data] & $0.070,0.182$ & $0.080,0.251$ & $0.056,0.102$ & $0.036,0.082$ \\
\hline$\Delta \rho_{\max }, \Delta \rho_{\min }\left(\mathrm{e} \AA^{-3}\right)$ & $0.62,-2.19$ & $1.02,-1.99$ & $0.49,-0.43$ & $0.83,-0.49$ \\
\hline CCDC-\# & $2,090,559$ & $2,090,560$ & $2,090,561$ & $2,090,562$ \\
\hline
\end{tabular}

$C 2 / c$ with the cell parameters given in Table 1 . All hydrogen atoms were geometrically positioned, using the standard riding model with all $\mathrm{U}_{\text {iso }}$ fixed at 1.2 times the equivalent $\mathrm{U}_{\text {iso }}$ values of the attached carbon atoms. One fluorine atom was disordered over the two $\alpha$ positions and this was refined as a 75:25 disorder on F2A/F5B (and on the $\mathrm{H}$ atoms $\mathrm{H} 2 / \mathrm{H} 5$ vice versa, using some length fixing restraints. (see also "Discussion" section on this issue).

All hydrogen atoms of compound $\mathbf{4}$ were geometrically positioned, using the standard riding model with all $\mathrm{U}_{\text {iso }}$ fixed at 1.2 times the equivalent $U_{\text {iso }}$ values of the attached carbon atoms.

\section{Results and Discussion}

\section{Molecular Structure of $\left[\left(\mathrm{C}_{5} \mathrm{H}_{4} \mathrm{~F}\right) \mathrm{Mn}(\mathrm{CO})_{3}\right], 1$}

Compound 1 crystallizes in the monoclinic space group $P 2_{1} / n$ with one molecule in the asymmetric unit. Figure 1 shows the molecular structure. Important bond lengths and angles are collected in Table 2. The C1-F bond is in an eclipsed position to the $\mathrm{C} 7-\mathrm{O} 2$ carbonyl group, while the carbonyl group $\mathrm{C} 6-\mathrm{O} 1$ bisects the ring $\mathrm{C} 2-\mathrm{C} 3$ bond. This

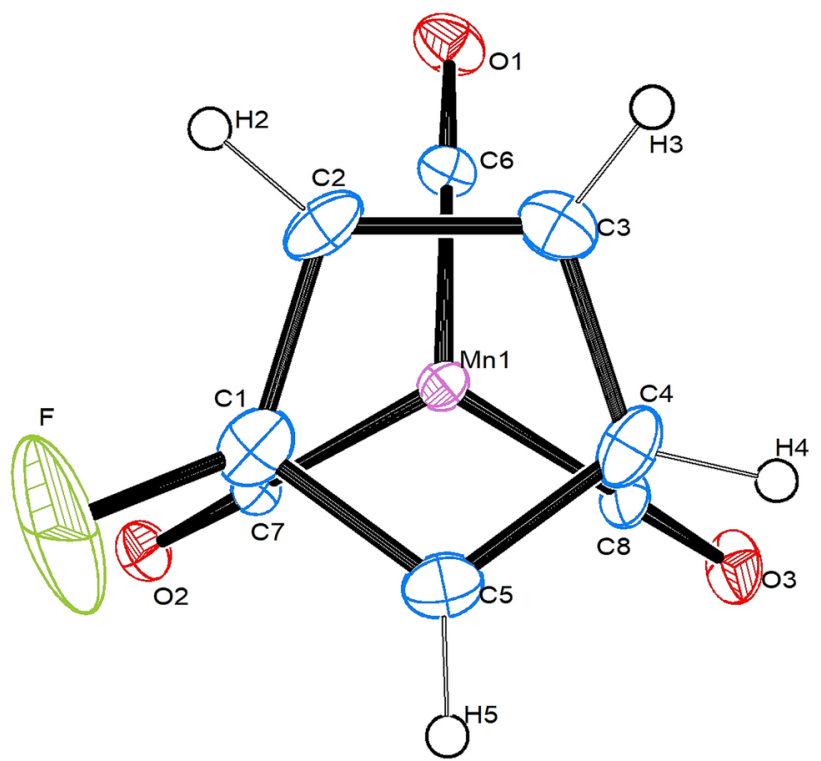

Fig. 1 Top view of compound 1. 30\% probability ellipsoids

situation is very similar to the situation found in $\left[\left(\mathrm{C}_{5} \mathrm{H}_{4} \mathrm{I}\right)\right.$ $\mathrm{Mn}(\mathrm{CO})_{3}$ ] [25]. There are three structure reports on compounds containing a $\mathrm{C}_{5} \mathrm{H}_{4} \mathrm{~F}$ ligand: $\left[\left(\mathrm{C}_{5} \mathrm{H}_{4} \mathrm{~F}\right) \mathrm{Fe}\left(\mathrm{C}_{5} \mathrm{H}_{5}\right)\right]$ 
Table 2 Important bond parameters of 1-4 and some related compounds

\begin{tabular}{|c|c|c|c|c|c|c|}
\hline compd & $\mathrm{C}-\mathrm{F}[\AA ⿻]$ & $\mathrm{Mn}-\mathrm{P}[\AA]$ & $\mathrm{Mn}-\mathrm{Ct}[\AA]$ & $\mathrm{OC}-\mathrm{Mn}-\mathrm{CO}\left[{ }^{\circ}\right]$ & $\mathrm{DCp}-\mathrm{F}[\AA]$ & Reference \\
\hline 1 & $1.280(11)$ & - & $1.768(3)$ & $\begin{array}{l}92.5(2) \\
92.8(3) \\
91.9(2)\end{array}$ & $0.038(9)$ & This work \\
\hline 2 (mol. A) & $\begin{array}{l}1.326(4) \\
\{1.260(15)\}\end{array}$ & $2.2352(8)$ & $1.7734(17)$ & $90.93(13)$ & $0.100(3)$ & This work \\
\hline 2 (mol.B) & $\begin{array}{l}1.322(5) \\
\{1.30(5)\}\end{array}$ & $2.2454(9)$ & $1.7742(19)$ & $92.01(13)$ & $0.091(3)$ & This work \\
\hline 3 & $\begin{array}{l}1.342(4) \\
1.303(3)\end{array}$ & $2.2375(8)$ & $1.7677(11)$ & $93.59(10)$ & $\begin{array}{l}0.067(2) \\
0.090(2)\end{array}$ & This work \\
\hline 4 & $\begin{array}{l}1.373(3) \\
1.364(4) \\
1.334(2)\end{array}$ & $2.2396(7)$ & $1.7638(9)$ & $93.86(9)$ & $\begin{array}{l}0.091(1) \\
0.080(1) \\
0.088(1)\end{array}$ & This work \\
\hline $\mathrm{CpMn}(\mathrm{CO})_{3}$ & - & - & 1.772 & $\begin{array}{l}91.85(11) \\
92.63(11) \\
91.94(12)\end{array}$ & - & {$[34]$} \\
\hline $\mathrm{CpMn}(\mathrm{CO})_{2} \mathrm{PPh}_{3}$ & - & $2.236(3)$ & 1.775 & $92.42(41)$ & - & {$[35]$} \\
\hline
\end{tabular}

"Ct" is the centroid of the cyclopentadienyl ring. $\mathrm{DCp}-\mathrm{F}$ is the distance of the fluorine atoms from the plane of the cyclopentadienyl ring
$[16,26],\left[\left(\mathrm{C}_{5} \mathrm{H}_{4} \mathrm{~F}\right)_{2} \mathrm{Fe}\right][23]$ and $\left[\left(\mathrm{C}_{5} \mathrm{H}_{4} \mathrm{~F}\right) \mathrm{Ru}\left(\mathrm{C}_{5} \mathrm{Me}_{5}\right)\right][14]$. The two reports on monofluoroferrocene have two different monoclinic unit cells. Whereas Inkpen et. al. report on a highly disordered structure, which prevented any meaningful geometric analysis, the report by Tazi et al. contains no structure discussion at all (however, inspection of the cif-file that can be obtained from the Cambridge Structural Database shows also severe disorder problems). In addition, the ruthenium compound shows severe disorder with the fluorine atom spread over three positions. Apparently the only compound without any structure solution problems is the $1,1^{\prime}$-difluoroferrocene. A C-F bond length of 1.357(3) $\AA$ is reported for this compound, while for the major components of the two mentioned disordered structures $\mathrm{C}-\mathrm{F}$ bond lengths of $1.344 \AA$ and $1.265(8) \AA$ are given. Thus the $\mathrm{C}-\mathrm{F}$ bond in $\mathbf{1}$ is at the shorter end of the observed distances. There are three intermolecular $\mathrm{C}-\mathrm{H} \cdots \mathrm{O}$ bonds: all three carbonyl oxygen atoms accept hydrogen bonds from $\mathrm{H}$ atoms $\mathrm{H} 4(\mathrm{O} 1$ and $\mathrm{O} 3)$ and $\mathrm{H} 2(\mathrm{O} 2)$. The individual molecules are linked in all directions via these interactions (Figure S1 and Table S1 of the Supporting information).

\section{Molecular Structure of $\left[\left(\mathrm{C}_{5} \mathrm{H}_{4} \mathrm{~F}\right) \mathrm{Mn}(\mathrm{CO})_{2}\left(\mathrm{PPh}_{3}\right)\right], 2$}

Compound 2 crystallizes in the triclinic space group $\mathrm{P}^{-} 1$ with two independent molecules in the unit cell. Figure 2 shows a top view of both molecules.

In both molecules the fluorine atom is disordered over two positions at $\mathrm{C} 3 / \mathrm{C} 6$ and $\mathrm{C} 33 / \mathrm{C} 35$, with one orientation clearly dominating ( $87 \%$ in A, $97 \%$ in B). An alternative interpretation (and quite possible regarding the contamination of $\mathbf{2}$ with 3 even after chromatography, [17] of the disorder would be co-crystallization of $\mathbf{2}$ and $\mathbf{3}$. Refinement of such a situation gave slightly worse R-values. However, this interpretation was discarded because of the fact, that $\mathbf{3}$ crystallizes in a different Bravais lattice. The two independent molecules could be transferred into each other by a cyclopentadienyl ring rotation of ca. $210^{\circ}$ around an axis through the cyclopentadienyl centroid and the manganese atom. Thus while the $\mathrm{C} 3-\mathrm{F} 1$ bond is nearly eclipsed with the $\mathrm{C} 2-\mathrm{O} 2$ carbonyl bond (torsion $\mathrm{C} 3-\mathrm{Ct} 1-\mathrm{Mn} 1-\mathrm{C} 2=-11.43^{\circ}$ ) in $\mathbf{A}$, the $\mathrm{C} 33-\mathrm{F} 2$ bond in $\mathbf{B}$ is eclipsed with the Mn2-P bond (torsion $\mathrm{C} 33-\mathrm{Ct} 2-\mathrm{Mn} 2-\mathrm{P} 2=6.96^{\circ}$ ). In molecule $\mathbf{A}$, the Mn1-P1 bond is nearly eclipsed with the C6-H6 bond (torsion $\mathrm{C} 6-\mathrm{Ct} 1-\mathrm{Mn} 1-\mathrm{P}=13.00^{\circ}$ ). The $\mathrm{C}-\mathrm{F}$ bonds in both molecules are identical within $1 \sigma$ and substantially longer than in compound $\mathbf{1}$. The distances from manganese to the cyclopentadienyl ring centroids are also identical in both molecules and slightly longer (ca. $2 \sigma$ ) than in $\mathbf{1}$. However, the Mn2-P2 bond is significantly longer $(>10 \sigma)$ than Mn1-P1, which is most likely due to the eclipsed $\mathrm{C}-\mathrm{F}$ bond. Both molecules form a large number of $\mathrm{C}-\mathrm{H} \cdots \mathrm{F}$ (two, both involving atom $\mathrm{F} 2$ ) and $\mathrm{C}-\mathrm{H} \cdots \mathrm{O}$ (nine, with $\mathrm{O} 1$ accepting even four and $\mathrm{O} 31$ three) hydrogen bonds (Figure S2 and Table S1 of the Supporting information). The conformational analysis of the $\mathrm{PPh}_{3}$ "propeller" will be discussed below.

\section{Molecular Structure of $\left[\left(\mathrm{C}_{5} \mathrm{H}_{3} \mathrm{~F}_{2}\right) \mathrm{Mn}(\mathrm{CO})_{2}\left(\mathrm{PPh}_{3}\right)\right], 3$}

Compound 3 crystallizes in the monoclinic space group $C 2 / c$ with one independent molecule in the asymmetric unit. Figure 3 shows a top view of the structure. 

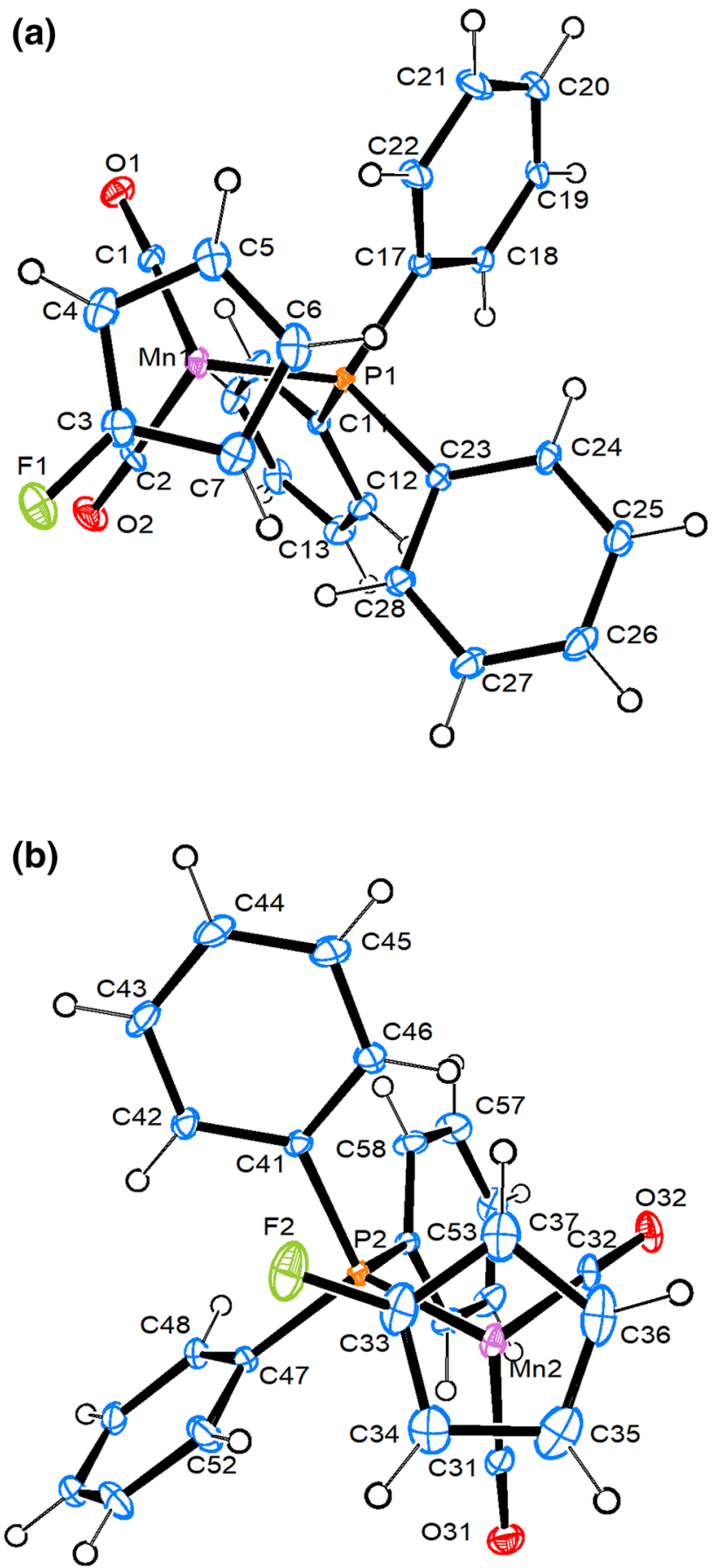

Fig. 2 a (left) Top view of compound 2, molecule A; b (right) top view of compound 2 molecule B. $30 \%$ probability ellipsoids

Fluorine atom F2 is disordered over two positions (at carbon atoms $\mathrm{C} 2$ and $\mathrm{C} 5$ ), with relative populations of 75 and $25 \%$. An alternative interpretation of this disorder would be co-crystallization of $\mathbf{3}$ and $\mathbf{4}$, which should be possible, since both compounds crystallize in the same space group with very similar cell parameters. Refinement under this assumption gave an approximate 2:1 ratio of $\mathbf{3}$ and $\mathbf{4}$, but also worse

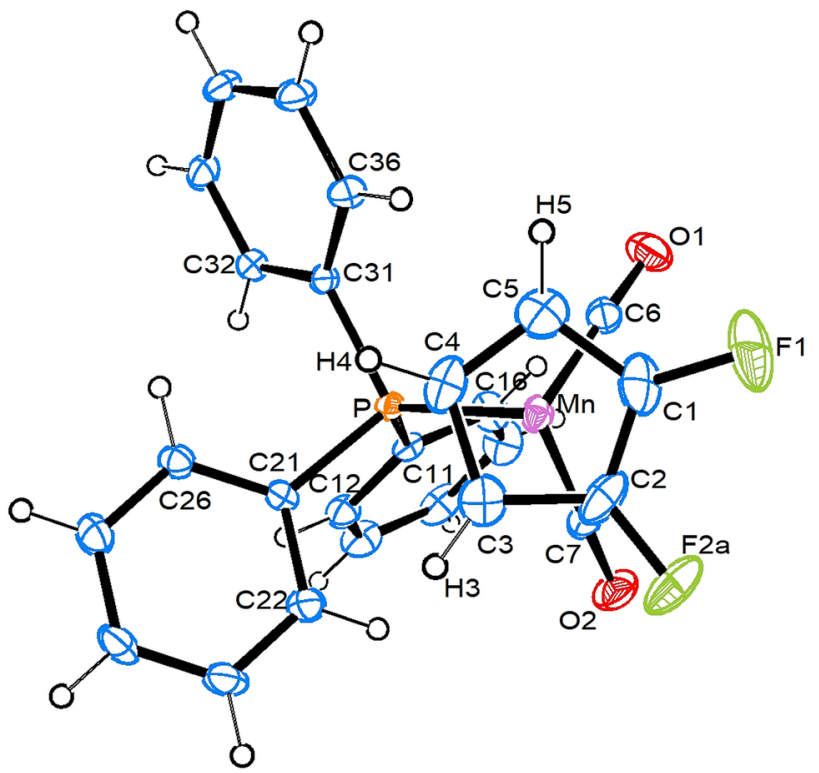

Fig. 3 Top view of the molecular structure of compound 3. $30 \%$ probability ellipsoids

$\mathrm{R} 1$ and wR2 values. This model was therefore discarded. One $\mathrm{C}-\mathrm{F}$ bond $(\mathrm{C} 1-\mathrm{F} 1)$ is nearly in trans position to the $\mathrm{Mn}-\mathrm{P}$ vector (torsion $\mathrm{C} 1-\mathrm{Ct}-\mathrm{Mn}-\mathrm{P}=-159.63^{\circ}$ ), while the other $\mathrm{C}-\mathrm{F}$ bond (major orientation) nearly eclipses with the $\mathrm{C} 7-\mathrm{O} 2$ bond (torsion $\mathrm{C} 2-\mathrm{Ct}-\mathrm{Mn}-\mathrm{C} 7=11.91^{\circ}$ ). The $\mathrm{C} 1-\mathrm{F} 1$ bond is significantly longer $(>10 \sigma)$ than $\mathrm{C} 2-\mathrm{F} 2 \mathrm{~A}$. Although it cannot be excluded, that this effect is "real", it might just be an artefact of an improperly treated disorder $\mathrm{F} 2 \mathrm{~A} / \mathrm{H} 2$ (at the same time, the C5-F5B bond is much too short, which is certainly due to the disorder F5B/H5). There is only one other structure report of a compound containing a $\mathrm{C}_{5} \mathrm{H}_{3} \mathrm{~F}_{2}$ ligand, i.e. $\left[\left(\mathrm{C}_{5} \mathrm{H}_{3} \mathrm{~F}_{2}\right) \mathrm{Ru}\left(\mathrm{C}_{5} \mathrm{Me}_{5}\right)\right]$ [14]. In this compound the two $\mathrm{C}-\mathrm{F}$ bond lengths were also very different, showed however relatively large standard deviations: 1.311(14) and 1.227(18) $\AA$. No discussion/ interpretation of this difference was presented.

In the crystal structure, molecules of $\mathbf{3}$ form sheets parallel to the $a b$ plane via $\mathrm{C} 34-\mathrm{H} 34 \cdots \mathrm{F} 1$ and $\mathrm{C} 13-\mathrm{H} 13 \cdots \mathrm{F} 2 \mathrm{~A}$ hydrogen bonds. These sheets are connected in $b$ and $c$ direction via three $\mathrm{C}-\mathrm{H} \cdots \mathrm{O}$ hydrogen bonds. (Table $\mathrm{S} 1$ and Figure S3 of the Supporting Information). The conformational analysis of the $\mathrm{PPh}_{3}$ "propeller" can be found below.

\section{Molecular Structure of $\left[\left(\mathrm{C}_{5} \mathrm{H}_{2} \mathrm{~F}_{3}\right) \mathrm{Mn}(\mathrm{CO})_{2}\left(\mathrm{PPh}_{3}\right)\right], 4$}

As mentioned above, compound $\mathbf{4}$ also crystallizes in the monoclinic space group $C 2 / c$ with one molecule in the asymmetric unit. Figure 4 shows a top view of the structure.

The structure is rather similar to the structure of $\mathbf{3}$. The bond $\mathrm{C} 2-\mathrm{F} 2$ is nearly in trans-position to the $\mathrm{Mn}-\mathrm{P}$ bond (torsion $\mathrm{C} 2-\mathrm{Ct}-\mathrm{Mn}-\mathrm{P}=161.75^{\circ}$ ), while $\mathrm{C} 3-\mathrm{F} 3$ eclipses 


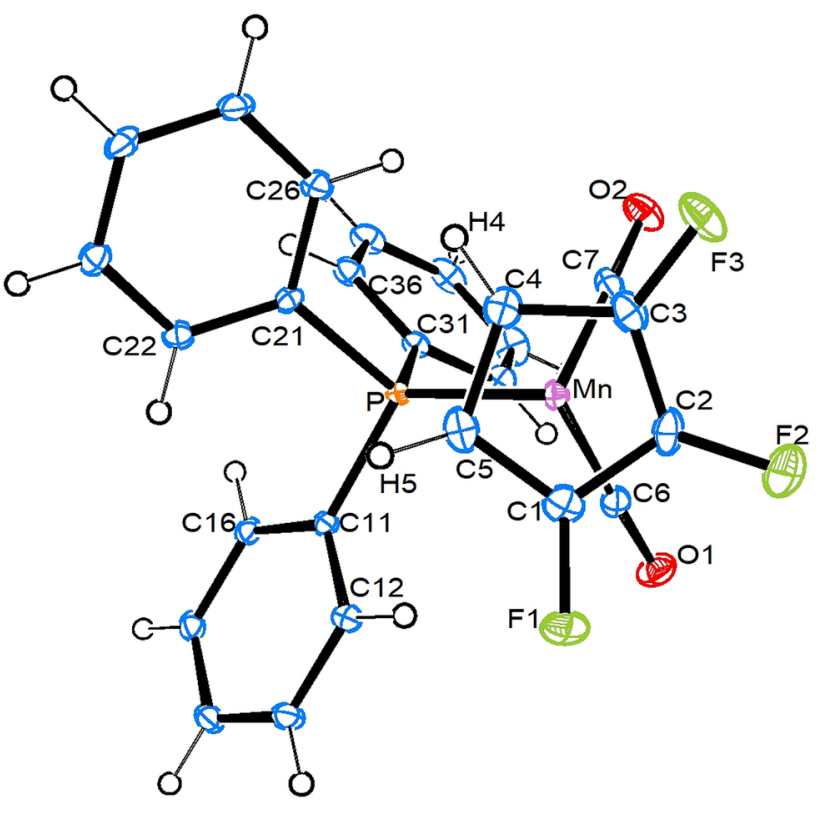

Fig. 4 Top view of compound 4. 30\% probability ellipsoids

the $\mathrm{C} 7-\mathrm{O} 2$ bond (torsion $\mathrm{C} 3-\mathrm{Ct}-\mathrm{Mn}-\mathrm{C} 7=-9.10^{\circ}$ ). The $\mathrm{Mn}-\mathrm{C} 6-\mathrm{O} 1$ bond bisects the $\mathrm{C} 1-\mathrm{C} 2$ bond of the cyclopentadienyl ring. The bonds $\mathrm{C} 1-\mathrm{F} 1$ and $\mathrm{C} 2-\mathrm{F} 2$ are identical within $2 \sigma$ and the longest $\mathrm{C}-\mathrm{F}$ bonds observed in this study. The third bond is substantially shorter, as was also observed in the structure of $\mathbf{3}$ for the $\mathrm{C}-\mathrm{F}$ bond eclipsed to a $\mathrm{C}-\mathrm{O}$ bond.

All C-F bonds are involved in hydrogen bonding (intermolecular $\mathrm{C} 15-\mathrm{H} 15 \cdots \mathrm{F} 1, \mathrm{C} 14-\mathrm{H} 14 \cdots \mathrm{F} 2, \mathrm{C} 35-\mathrm{H} 35 \cdots \mathrm{F} 3$ and intramolecular $\mathrm{C} 12-\mathrm{H} 12 \cdots \mathrm{F} 1$ ), creating chains along the $b c$ diagonal that are cross-linked perpendicular to this direction (Table S1 and Fig. 5). Additionally, there is also a system of $\mathrm{C}-\mathrm{H} \cdots \mathrm{O}$ hydrogen bonds that connects the molecules in $b$ direction (Table S1 and Fig. S4).

Although there are apparently "channels" in this structure, careful analysis by PLATON shows that there are no solvent accessible voids. The discussion of the conformational analysis of the $\mathrm{PPh}_{3}$ ligand can be found in the next chapter.

\section{Conformational Analysis of the $\mathrm{PPh}_{3}$ Ligands in 2-4}

There has been a controversy for quite a long time about which parameters are the most important for the conformational parameters in [(Arene)LL' $\left.\mathrm{M}\left(\mathrm{PPh}_{3}\right)\right]$ complexes [27-33]. For the following discussion, we follow the definitions and arguments of the Brunner group. For better understanding, Fig. 6 shows a wireframe projection down the $\mathrm{P} \rightarrow \mathrm{Mn}$ vector in compound $\mathbf{4}$ (corresponding presentations of the other compounds can be found in the Supporting Information).

The "propeller angle" $\tau_{\mathrm{j}}$ is defined by the absolute value of the torsion angle ${ }^{\text {out }} \mathrm{C}_{\mathrm{o}}(\mathrm{j})-\mathrm{C}_{\mathrm{i}}(\mathrm{j})-\mathrm{P}-\mathrm{Mn}$; the "gauche angle" $\rho_{\mathrm{j}}$ by the absolute value of the torsion angle $\mathrm{Ct}-\mathrm{Mn}-\mathrm{P}-\mathrm{C}_{\mathrm{i}}(\mathrm{j})$

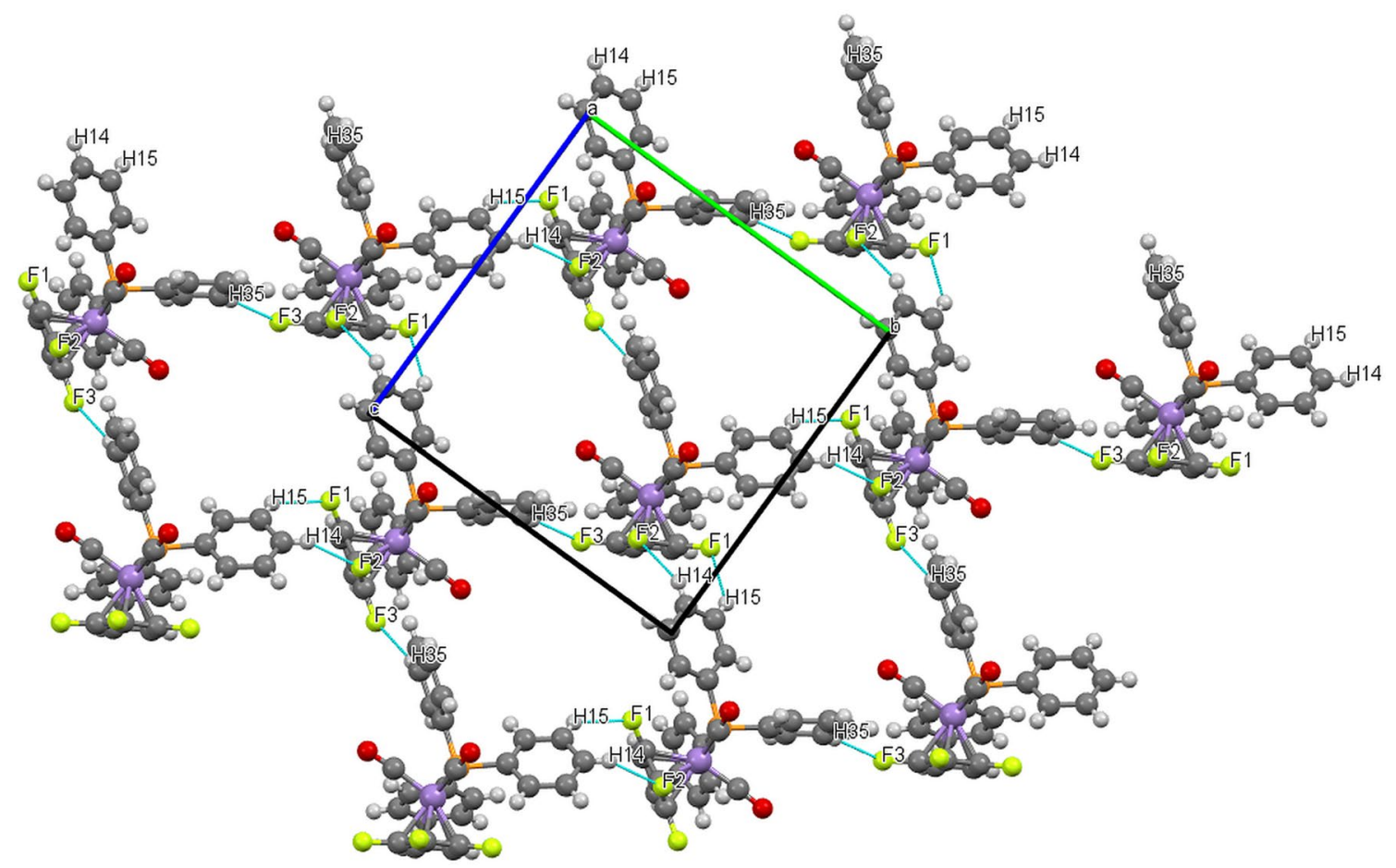

Fig. 5 Packing diagram (MERCURY) of $\mathbf{4}$ viewed along $a$ 
Fig. 6 Wireframe projection along the $\mathrm{P} \rightarrow \mathrm{Mn}$ vector in compound 4

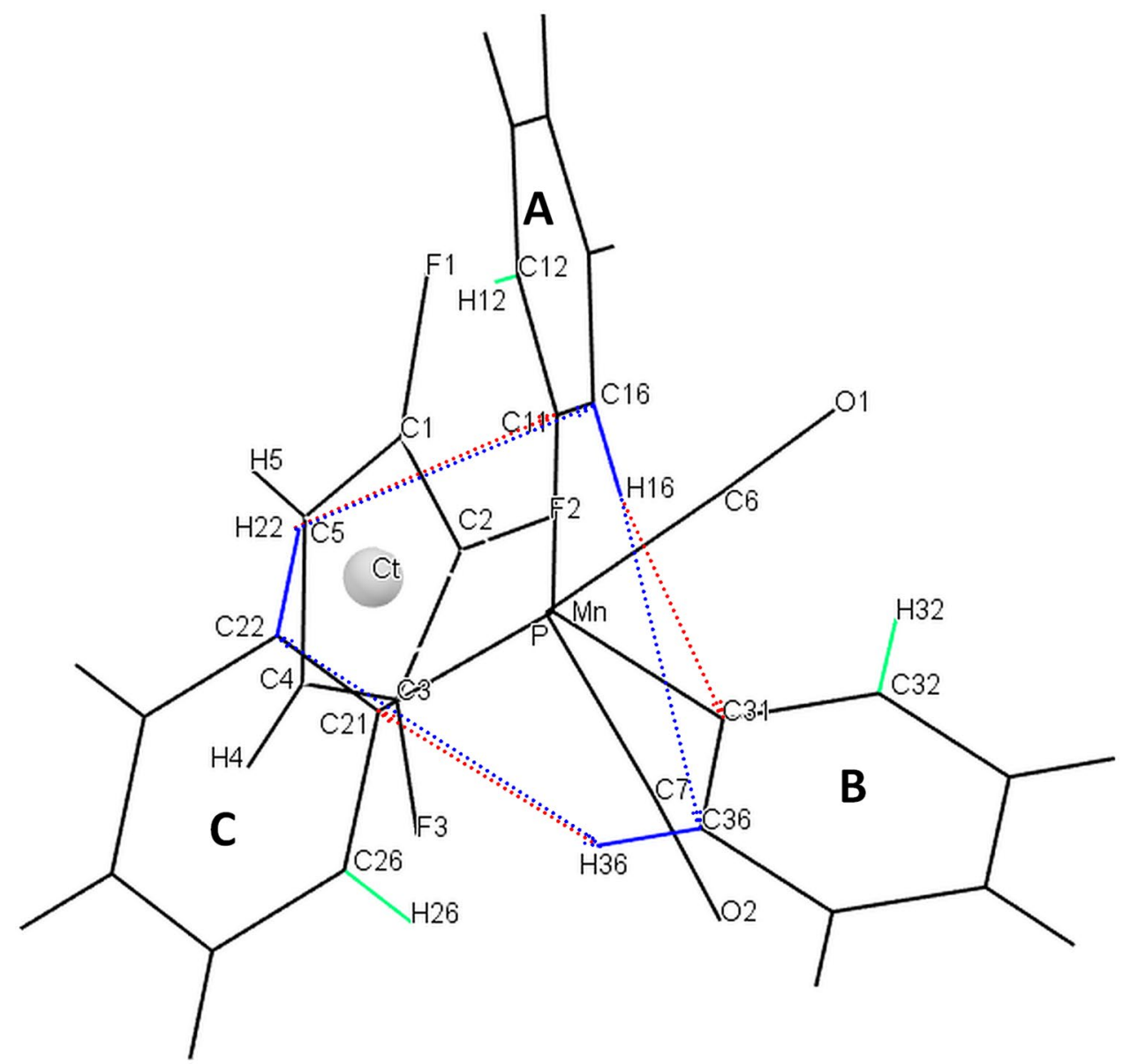

and $\varphi_{\mathrm{j}}$ is the interplanar angle between the plane of the cyclopentadienyl ring and phenyl ring " $\mathrm{j}$ ”. " $\mathrm{j}$ " stands either for "A", "B" or "C". For every phenyl ring there is one ipso carbon $\mathrm{C}_{\mathrm{i}}(\mathrm{j})$ and two ortho carbons, ${ }^{\text {out }} \mathrm{C}_{\mathrm{o}}(\mathrm{j})$ and ${ }^{\text {in }} \mathrm{C}_{\mathrm{o}}(\mathrm{j})$. "out" and "in" refer to the relative positions of these carbon atoms towards the plane of the three ipso carbon atoms: "in" lies between the three phenyl rings of the propeller, "out" on the side closer to the metal atom. In Fig. 6, the three ${ }^{\text {in }} \mathrm{C}_{\mathrm{o}}-\mathrm{H}$ bonds are marked blue and the three ${ }^{\text {out }} \mathrm{C}_{\mathrm{o}}-\mathrm{H}$ bonds are green. The red arrows represent the ${ }^{\text {in }} \mathrm{C}_{0} \mathrm{H}(\mathrm{j}) \rightarrow \mathrm{C}_{\mathrm{i}}\left(\mathrm{j}^{\prime}\right)$ distances and the blue arrows the ${ }^{\text {in }} \mathrm{C}_{0} \mathrm{H}(\mathrm{j}) \rightarrow{ }^{\text {in }} \mathrm{C}_{\mathrm{o}}\left(\mathrm{j}^{\prime}\right)$. The assignment of the letters $\mathrm{A}, \mathrm{B}, \mathrm{C}$ is based on the following rule: ring $\mathrm{A}$ is the ring with the smallest "propeller angle" $\tau$. Ring $B$ is that ring for which ${ }^{\text {in }} \mathrm{C}_{0} \mathrm{H}(\mathrm{A}) \rightarrow \mathrm{C}_{\mathrm{i}}\left(\mathrm{j}^{\prime}\right)<2.9 \AA$, and ring $\mathrm{C}$ is, of course, the only ring left. For compound 4 (Fig. 5) ring A corresponds to C11-C16 ring B to C31-C36 and ring $\mathrm{C}$ to $\mathrm{C} 21-\mathrm{C} 26$. With these definitions, the parameter list shown in Table 3 can be collected.

When looking at the propeller angles of ring $\mathrm{A}$, one sees that they are rather small except for molecule B of compound 2. Inspection of Fig. 2 immediately shows the reason for this: The bond C33-F2 eclipses the $\mathrm{Mn} \rightarrow \mathrm{P}$ vector, while in all other cases (at least in the major orientations) the CF groups
Table 3 Typical conformational parameters of the $\mathrm{PPh}_{3}$ ligands in 2-4

\begin{tabular}{|c|c|c|c|c|}
\hline Angle $\left[{ }^{\circ}\right] /$ distance $[\AA]$ & 2/mol. A & 2/mol. B & 3 & 4 \\
\hline$\tau_{\mathrm{A}}$ & 20.45 & 32.50 & 13.38 & 15.01 \\
\hline$\tau_{\mathrm{B}}$ & 60.41 & 56.88 & 46.33 & 46.86 \\
\hline$\tau_{\mathrm{C}}$ & 51.84 & 46.91 & 43.42 & 54.69 \\
\hline$\rho_{\mathrm{A}}$ & 80.51 & 82.43 & 76.77 & 78.53 \\
\hline$\rho_{\mathrm{B}}$ & 159.89 & 158.4 & 160.67 & 159.04 \\
\hline$\rho_{\mathrm{C}}$ & 41.43 & 40.81 & 43.42 & 41.31 \\
\hline$\varphi_{\mathrm{A}}$ & 57.59 & 70.1 & 51.24 & 51.17 \\
\hline$\varphi_{\mathrm{B}}$ & 70.59 & 62.3 & 69.56 & 68.08 \\
\hline$\varphi_{\mathrm{C}}$ & 20.05 & 18.6 & 17.87 & 20.26 \\
\hline${ }^{\mathrm{in}} \mathrm{C}_{\mathrm{o}} \mathrm{H}(\mathrm{A}) \rightarrow \mathrm{C}_{\mathrm{i}}(\mathrm{B})$ & 2.661 & 2.6223 & 2.809 & 2.799 \\
\hline${ }^{\mathrm{in}} \mathrm{C}_{\mathrm{o}} \mathrm{H}(\mathrm{A}) \rightarrow{ }^{\mathrm{in}} \mathrm{C}_{\mathrm{o}}(\mathrm{B})$ & 3.055 & 2.988 & 2.964 & 2.964 \\
\hline${ }^{\mathrm{in}} \mathrm{C}_{\mathrm{o}} \mathrm{H}(\mathrm{B}) \rightarrow \mathrm{C}_{\mathrm{i}}(\mathrm{C})$ & 2.573 & 2.564 & 2.541 & 2.554 \\
\hline${ }^{\mathrm{in}} \mathrm{C}_{\mathrm{o}} \mathrm{H}(\mathrm{B}) \rightarrow{ }^{\mathrm{in}} \mathrm{C}_{\mathrm{o}}(\mathrm{C})$ & 3.330 & 3.804 & 3.146 & 3.205 \\
\hline${ }^{\text {in }} \mathrm{C}_{\mathrm{o}} \mathrm{H}(\mathrm{B}) \rightarrow{ }^{\text {out }} \mathrm{C}_{\mathrm{o}}(\mathrm{C})$ & 2.668 & 2.605 & 2.794 & 2.773 \\
\hline${ }^{\mathrm{in}} \mathrm{C}_{\mathrm{o}} \mathrm{H}(\mathrm{C}) \rightarrow \mathrm{C}_{\mathrm{i}}(\mathrm{A})$ & 2.648 & 2.636 & 2.591 & 2.582 \\
\hline${ }^{\mathrm{in}} \mathrm{C}_{\mathrm{o}} \mathrm{H}(\mathrm{C}) \rightarrow{ }^{\mathrm{in}} \mathrm{C}_{\mathrm{o}}(\mathrm{A})$ & 2.843 & 2.908 & 2.651 & 2.664 \\
\hline
\end{tabular}

Definitions of angles $\tau, \rho, \varphi$ and "in" and "out" see text. $\mathrm{C}_{\mathrm{i}}$ is the ipso carbon, $\mathrm{C}_{\mathrm{o}}$ are the ortho carbon atoms of the phenyl ring 
have $\mathrm{P}-\mathrm{Mn}-\mathrm{Ct}-\mathrm{C}_{\mathrm{F}}$ torsions $>>90^{\circ}$. Because of this, the other angles $\rho$ and $\varphi$ apparently show no correlation with the number of fluorine substituents on the cyclopentadienyl ring. Most of the ${ }^{{ }^{i n}} \mathrm{C}_{\mathrm{o}} \mathrm{H} \rightarrow \mathrm{C}_{\mathrm{i}}$ distances are around $2.60 \pm 0.05 \AA$ and hint therefore to rather strong $\mathrm{C}-\mathrm{H}-\pi$ interactions. The only exemptions are the ${ }^{\text {in }} \mathrm{C}_{\mathrm{o}} \mathrm{H}(\mathrm{A}) \rightarrow \mathrm{C}_{\mathrm{i}}(\mathrm{B})$ distances for 3 and $\mathbf{4}$, which are about $0.20 \AA$ longer. However, also these values still are below the some of the van-der-Waals radii.

The appearance of rather small $\varphi$ angles for ring $C$ in all compounds hint on the existence of the bonding motif "Ph ${ }_{\mathrm{PPh} 3}$-Face-On- $\pi$ Aryl" [27-30], however, the rather large distances $\mathrm{C}_{\mathrm{cp}}-\mathrm{C}_{\mathrm{i}}$ (ring $\mathrm{C}$ ) show that this interaction is here rather unimportant.

\section{Conclusions}

Replacing one carbonyl ligand of compound $\mathbf{1}$ for one $\mathrm{PPh}_{3}$ ligand leads to an increase of the $\mathrm{C}-\mathrm{F}$ bond length by $0.04 \AA^{3}$. Successive introduction of fluorine substituents leads to further lengthening of the C-F bonds by ca. $0.02 \AA$ for each fluorine. The lengths of the Mn-P bonds and the distances from $\mathrm{Mn}$ to the cyclopentadienyl ring centroid are not affected by the increasing fluorine content. Nearly always, the $\mathrm{Mn} \rightarrow \mathrm{P}$ vector is in a transoid orientation relative to the $\mathrm{C}-\mathrm{F}$ bonds, and therefore the conformations of the $\mathrm{PPh}_{3}$ propellers are hardly influenced by increasing fluorine content. However, when the Mn-P bond eclipses with a $\mathrm{C}-\mathrm{F}$ bond, it becomes significantly longer, and the propeller angles "flatten". This mutual "avoiding" of Mn-P and $\mathrm{C}-\mathrm{F}$ bonds would become impossible, when a further fluorine substituent should be introduced. This might be an explanation, why, at least up to now, it was not possible to prepare fluorocymantrenes with a higher fluorine content.

Supplementary Information The online version contains supplementary material available at https://doi.org/10.1007/s10870-021-00898-x.

Acknowledgements We thank Dr. P. Mayer for performing the X-ray measurements.

Funding Open Access funding enabled and organized by Projekt DEAL. The authors did not receive support from any organization for the submitted work

\section{Declarations}

Conflict of interest The authors have no conflict of interest to declare that are relevant to the content of this article.

Open Access This article is licensed under a Creative Commons Attribution 4.0 International License, which permits use, sharing, adaptation, distribution and reproduction in any medium or format, as long as you give appropriate credit to the original author(s) and the source, provide a link to the Creative Commons licence, and indicate if changes were made. The images or other third party material in this article are included in the article's Creative Commons licence, unless indicated otherwise in a credit line to the material. If material is not included in the article's Creative Commons licence and your intended use is not permitted by statutory regulation or exceeds the permitted use, you will need to obtain permission directly from the copyright holder. To view a copy of this licence, visit http://creativecommons.org/licenses/by/4.0/.

\section{References}

1. Berger R, Resnati G, Metrangolo P, Weber E, Hulliger J (2011) Chem Soc Rev 40:3496-3508

2. Cametti M, Crousse B, Metrangelo P, Milani R, Resnati G (2012) Chem Soc Rev 41:31-42

3. Purser S, Moore PR, Swallow S, Gouverneur V (2008) Chem Soc Rev 37:320-330

4. Preshlock S, Tredwell M, Gouverneur V (2016) Chem Rev 116:719-766

5. Siegmund D, Metzler-Nolte N (2020). In: Weigand W, Apfel U-P (eds) Bioorganometallic chemistry, vol 2020. De Gruyter, Berlin, Boston, pp 319-350

6. Sansook S, Hassel-Hart S, Ocasio C, Spencer J. (2020) J. Organomet. Chem. 905, 121017

7. Patra M, Gasser G (2017) Nat Rev Chem 1:0066

8. Tazi M, Erb W, Roisnel T, Dorcet V, Mongin F, Low PJ (2019) Org Biomol Chem 17:9352-9359

9. Sünkel K, Weigand S (2011) 2-Pyridylmetallocenes: Part I. Inorg Chim Acta 370:224-229

10. Cais M, Narkis N (1965) J Organomet Chem 3:269-273

11. Hedberg FL, Rosenberg H (1971) J Organomet Chem 28:C14-C16

12. Curnow OJ, Hughes RP (1992) J Am Chem Soc 114:5895-5897

13. Hughes RP, Zheng X, Rheingold AL, Ostrander RL (1994) Organometallics 13:1567-1568

14. Hughes RP, Zheng X, Morse CA, Curnow OJ, Lomprey JR, RheingoldYap ALGPA (1998) Organometallics 17:457-465

15. Erb W, Roisnel T (2019) Chem Commun 55:9132-9135

16. Tazi M, Hedidi M, Erb W, Halauki YS, Ivashkevich OA, Matulis VE, Roisnel T, Dorcet V, Bentabed-Ababsa G, Mongin F (2018) Organometallics 37:2207-2211

17. Klein-Heßling C, Blockhaus T, Sünkel K (2021). J Organomet Chem. https://doi.org/10.1016/j.jorganchem.2021.121833

18. Wu K, Park JY, Al-Sadoon R, Nam H, Lee Y, Top S, Jaouen G, Baik M-H, Geiger WE (2018) Organometallics 37:1910-1918

19. Wu K, Pudasaini B, Park JY, Top S, Jaouen G, Baik M-H, Geiger WE (2020) Organometallics 39:679-687

20. Groom CR, Bruno IJ, Lightfoot MP, Ward SC (2016) Acta Cryst B 72:171-179

21. Farrugia LJ (2012) J Appl Cryst 45:849-854

22. Burla MC, Caliandro R, Carrozzini B, Cascarano GL, Cuocci C, Giacovazzo C, Mallamo M, Mazzone A, Polidori G (2015) J Appl Cryst 48:306-309

23. Sheldrick GM (2015) Acta Cryst A 71:3-8

24. Sheldrick GM (2015) Acta Cryst C 71:3-8

25. Romanov AS, Mulroy JM, Antipin MY, Timofeeva TV (2009) Acta Cryst C 65:m431-m435

26. Inkpen MS, Du S, Hildebrand M, White AJP, Harrison NM, Albrecht T, Long NJ (2015) Organometallics 34:5461-5469

27. Brunner H, Hammer B, Krüger C, Angermund K, Bernal I (1985) Organometallics 4:1063-1068

28. Brunner H, Tsuno $T$ (2016) Inorg Chim Acta 446:132-142

29. Brunner H, Tsuno T (2017) Dalton Trans 46:5103-5109

30. Brunner H, Balazs G, Tsuno T, Iwabe H (2018) ACS Omega 3:982-990

31. Costello JF, Davies SG (1998) J Chem Soc Perkin Trans 2:1683-1689 
32. Costello JF, Davies SG, McNally D (1999) J Chem Soc Perkin Trans 2:465-473

33. Costello JF, Davies SG, Gould ETF, Thomson JE (2015) Dalton Trans 44:5451-5466

34. Cowie J, Hamilton EJM, Laurie JCV, Welch AJ (1990) J Organomet Chem 394:1-13

35. Barbeau C, Sorrento Dichmann K, Ricard L (1973) Can J Chem 51:3027-3031
Publisher's Note Springer Nature remains neutral with regard to jurisdictional claims in published maps and institutional affiliations. 